\title{
Multiple foreign body aspiration
}

\author{
Pierre Goussard, Julie Lyn Morrison, Ilse Nadine Appel, Lindy-Lee Green
}

Department of Paediatrics and Child Health, Stellenbosch University Faculty of Medicine and Health Sciences, Cape Town, South Africa

\section{Correspondence to} Professor Pierre Goussard, pgouss@sun.ac.za

Accepted 10 March 2017

\section{DESCRIPTION}

A baby girl aged 3 years 8 months presented 8 months earlier with a history of cough and tight chest for 3 days prior to admission. On chest examination, the child had bilateral wheezing, was mildly distressed and had reduced air entry on the right side over the middle and lower zone. Chest $\mathrm{X}$-ray demonstrated a round object in the oesophagus, but also collapse of the right middle and lower lobes (figure 1A). A metal washer was removed from the oesophagus at the cricopharyngeal level with a rigid scope. The child was then admitted postoperatively to paediatric intensive care unit for aspiration pneumonia. Considerable oesophageal mucosal inflammation was present at the site of the foreign body with no associated perforation. Contrast study performed at that stage demonstrated some narrowing of the oesophagus which did not need dilatation (figure 1B). Eight months later, she presented with respiratory distress and clinically reduced air entry over the right middle and lower lobe with dullness to percussion and bronchial breathing. Acute pneumonia of the right middle and lower lobe with volume loss was diagnosed (figure 1C).

Ultrasound scan confirmed consolidation but no effusion present. There was no response to amoxicillin clavulanate antibiotic and bronchoscopy was performed after a week's treatment. Pus was visible in the trachea and the right main bronchus. Significant granulation tissue was observed in the bronchus intermedius. A fragment of chicken bone was removed from the right main bronchus with a rigid bronchoscope (figure 2A). Oral corticosteroids were given for 5 days in order to reduce the amount of inflammation present in the airway. The child needed ventilation for 24 hours and was then successfully extubated. Repeat bronchoscopy was performed after 5 days due to a significant granulation tissue observed at the first bronchoscopy.

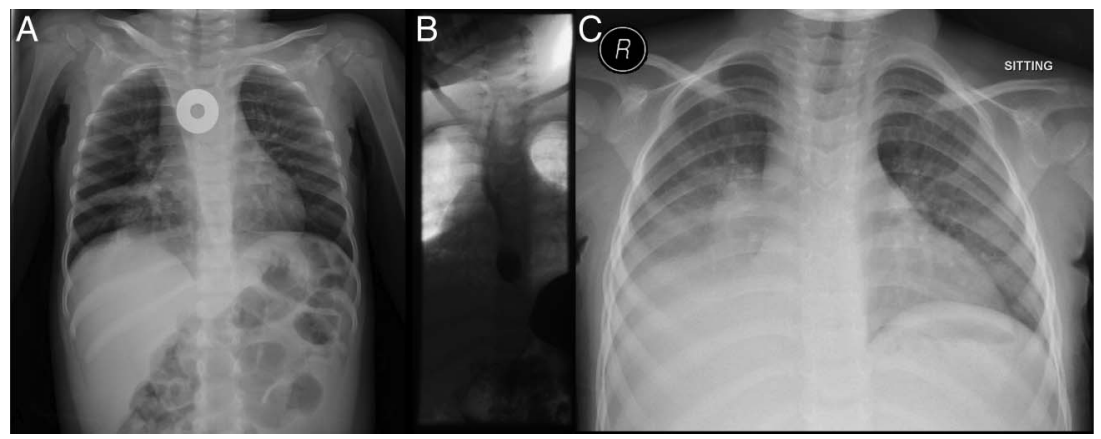

Figure 1 (A) Chest X-ray demonstrating round foreign body in the oesophagus, with signs of right lower lobe pneumonia. (B) Contrast study demonstrating a narrowing in oesophagus and complete collapse of the right middle and lower lobe. (C) Chest X-ray performed 8 months after aspiration of foreign body in oesophagus. Child presents with acute pneumonia of the right middle and lower lobe.

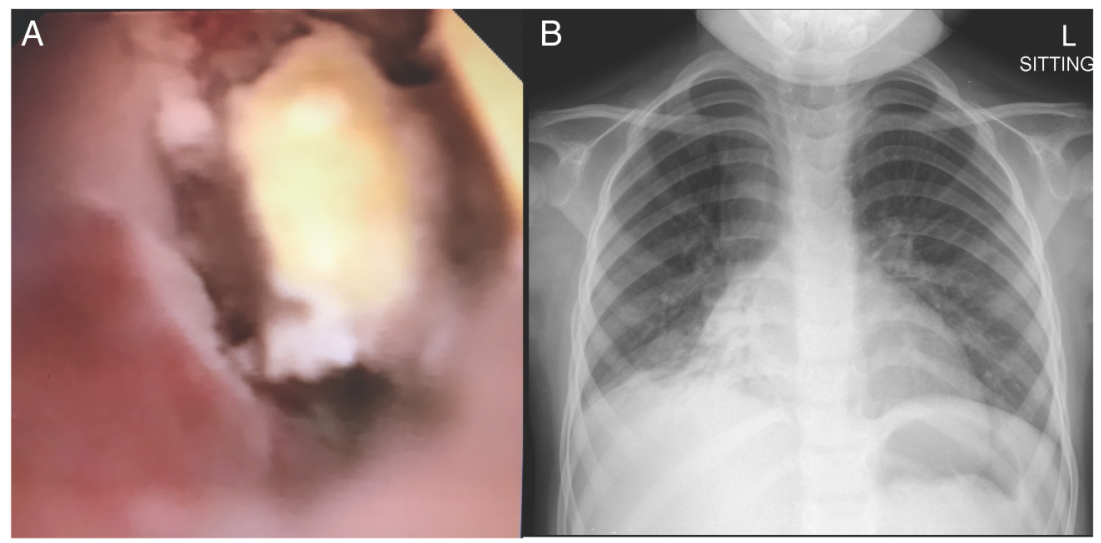

Figure 2 (A) Bronchoscopy picture of inhaled chicken bone in right bronchus intermedius with granulation tissue formed. (B) Chest X-ray performed 2 weeks after removal of foreign body shows some resolution of the right middle and lower lobe collapse. 
The granulation tissue had significantly reduced at repeat bronchoscopy; however, a second fragment of chicken bone was found in the left main bronchus, which was removed with a flexible bronchoscope. Repeat oesophageal endoscopy was performed at this time, which showed no narrowing or stricture.

A third bronchoscopy was performed 4 weeks later, which showed no signs of granulation tissue. The repeat chest X-ray showed significant improvement of consolidation and volume loss in the right lower lobe (figure $2 \mathrm{~B}$ ).

This child came with the unusual presentation of simultaneous foreign bodies in the oesophagus and the bronchus. One can postulate that the obstruction of the oesophagus may have complicated swallowing and predisposed to aspiration of the chicken bone. An extensive literature search was performed; however, we could not find any cases of simultaneous aspiration of both foreign bodies in the airway and oesophagus.

We suggest that after the extraction of a foreign body in the upper digestive tract, with the persistence of abnormal radiological images and clinical symptoms, one has to search for associated lesions and/or other foreign bodies. Furthermore, it is important to consider aspiration of foreign material into the airways when lung collapse is present with a foreign body in the oesophagus. The main potential clinical complication of impacted foreign bodies in the oesophagus is aspiration pneumonia. ${ }^{1}$ One must consider that due to obstruction of the oesophagus, the child may be at additional high risk of aspirating material into the airways and we suggest that bronchoscopy be performed during the same session as oesophageal endoscopy. Another important issue is that follow-up bronchoscopy must be performed when there is significant granulation tissue or pus within the airways as fragments of the same foreign body or additional foreign bodies may be missed during the initial endoscopy attempts. Bronchoscopy is made more complicated and difficult by the presence of granulation tissue and the sequelae of prolonged non-treatment results in a higher rate of chronic respiratory disease. Neeff reported that in children with a history of choking of more than 2 weeks before attempted removal have significant intraoperative granulation tissues. Granulation tissue was present in $89 \%$ of patients and $46 \%$ of patients had more than $50 \%$ obstruction of the lumen. ${ }^{2} 3$

\section{Learning points}

- Persistent collapse of a lobe should be investigated in children with aspirated foreign bodies in the oesophagus.

- Repeated bronchoscopy must be considered in children where there is a significant amount of pus and/or granulation tissue present at the initial bronchoscopy, to exclude missed foreign bodies.

- Multiple foreign bodies are rare but must be considered if lobar collapse persists.

\section{Acknowledgements Bronchoscopy theatre staff.}

Contributors PG was responsible for foreign body removal, JLM and L-LG were responsible for the care of patient and INA was responsible for care of the patient in the ICU.

Competing interests None declared.

Patient consent Obtained.

Provenance and peer review Not commissioned; externally peer reviewed.

\section{REFERENCES}

1 Berdan EA, Sato TT. Pediatric airway and esophageal foreign bodies. Surg Clin North Am 2017;1:55-91.

2 Martin A, van der Meer G, Blair D, et al. Long-standing inhaled foreign bodies in children: characteristics and outcome. Int J Pediatr Otorhinolaryngol 2016;90:49-53.

3 Tenenbaum $T$, Kähler $G$, Janke $C$, et al. Management of foreign body removal in children by flexible bronchoscopy. J Bronchology Interv Pulmonol 2017;24:21-8.

Copyright 2017 BMJ Publishing Group. All rights reserved. For permission to reuse any of this content visit

http://group.bmj.com/group/rights-licensing/permissions.

BMJ Case Report Fellows may re-use this article for personal use and teaching without any further permission.

Become a Fellow of BMJ Case Reports today and you can:

- Submit as many cases as you like

- Enjoy fast sympathetic peer review and rapid publication of accepted articles

- Access all the published articles

- Re-use any of the published material for personal use and teaching without further permission

For information on Institutional Fellowships contact consortiasales@bmjgroup.com

Visit casereports.bmj.com for more articles like this and to become a Fellow 